\title{
REPRESENTASI IDENTITAS DAN ETNISITAS MINANG DALAM NOVEL PERSIDEN KARYA WISRAN HADI
}

\author{
Sugiarti \\ Universitas Muhammadiyah Malang
}

\begin{abstract}
Abstrak
Identitas dan etnisitas merupakan konsep yang dikontruksi secara budaya. Keduanya merupakan bagian yang tidak terpisahkan dengan kehidupan manusia. Pencirian tersebut memperkuat jati diri manusia sebagai makhluk berbudaya yang selalu berhadapan dengan gejala sosial yang ada dalam realitas kehidupan masyarakat. Keseluruhan gejala sosial yang ada dalam kehidupan tidak dapat dilepaskan dengan hasil cipta sastra. Dia merupakan khasanah budaya yang memiliki fungsi penting dalam membangun khasanah dunia sastra. Wisran Hadi dalam novel Persiden mengungkapkan gejala sosial yang terjadi pada masyarakat Minang dengan identitas rumah Bagonjong sebagai simbol etnis. Simbol ini mempunyai kekuatan mengatur perilaku manusia yang berada pada komunitas etnis yang tercermin dari subjektivitas dan individualitas dengan berbagai persoalan yang dihadapi. Simbol sebagai representasi identitas dan. etnisitas termasuk dua elemen yang inheren dan sensitif dalam diri masyarakat Minang. Dalam novel karya Wisran Hadi identitas dan etnisitas sebagai sesuatu yang hidup, bereksistensi dalam interaksi tokohtokoh dalam cerita. Proses interaksi dan interelasi antartokoh-tokoh dalam cerita mampu merepresentasikan berbagai hal terkait dengan rumah Bagonjong sebagai warisan leluhur, idealisme hidup terhadap warisan budaya, silsilah keluarga, pembagian hak warisan budaya, gaya hidup masyarakat, prinsip hidup dalam menyikapi rasa malu, kedudukan suami hanya sebagai pembuat keturunan. Keseluruhan budaya, baik secara material dan nonmaterial merupakan kekuatan yang membentuk dalam satu kesatuan untuk menyatukan dengan ruh budaya Minang secara total meskipun berbagai problem yang dihadapi tokoh tidak dapat terselesaikan.
\end{abstract}

Kata kunci: budaya Minang, identitas, etnisitas, representasi

\begin{abstract}
Identity and ethnicity are cultural constructed concepts. Both are integral part of human life. Strengthen the characterization of human identity as civilized creatures are always faced with social phenomenon that exists in the reality of community life. Overall social phenomena that there in life cannot be detached with the results of literary reserved. He is a cultural treasure they have important functions in building a treasures the world literature. Wisran Hadi in Persiden revealed novel a social phenomenon that occurs in the Minang community identity as a symbol of ethnic Bagonjong home. This symbol has the power regulate human behavior that is reflected in the ethnic communities of subjectivity and individuality with the problems. Symbol as the identity and ethnicity representation included two inherent sensitive elements in the community of Minang. In the novel Persiden identity and ethnicity are as a living, to exist in the interaction of the characters in the story. The process of interaction and interrelation between the characters in the story represent a range of issues related to home Bagonjong as the heritage, idealism live on cultural heritage, family tree, sharing cultural heritage rights, lifestyle, the principle life in addressing the shame, husband the position just as a maker of descent. The overall culture of some materials and non-materials are the strengths that make up the unity of the spirit to unite with a total of Minang culture although the various problems faced by character cannot be solved.
\end{abstract}

Keywords: Minang culture, identity, ethnicity, representation 


\section{Pendahuluan}

Sastra sebagai hasil seni tidak terbatas pada seni sastra yang bersifat imajinatif karena sastra mengungkap berbagai fenomena sosial yang terjadi dalam masyarakat. Sebagai hasil proses impresi, kreasi, dan imajinasi, sastra memiliki peran penting dalam kehidupan manusia, karena sastra mempunyai fungsi dulce et utile (menyenangkan dan bermanfaat) bagi pembaca.

Karya sastra adalah produk masyarakat, yang tercipta karena adanya energi imajinatif dan luapan perasaan pengarang yang disampaikan secara lisan dan tulisan ke tengah-tengah masyarakat. Sebagai karya seni, karya sastra memiliki peranan penting dalam kehidupan manusia. Sastra berfungsi sebagai pendukung nilai-nilai kultural yang bersifat efektif kumulatif. Artinya, sastra mempunyai kekuatan untuk mengungkapkan segala sesuatu yang terkait dengan kehidupan manusia serta dinamikanya. Oleh karena itu, sastra mempunyai struktur yang koheren dan terpadu mengenai hubungan manusia dengan manusia, alam, dan zamannya (Sugiarti, 2009).

Pada dasarnya sastra tidak dapat dilepaskan dengan gejala-gejala sosial yang terjadi dalam masyarakat. Gejala tersebut bukanlah realitas tunggal dan bukan mekanisme yang bebas dari kompleksitas sistem makna. Gejala sosial tidak dapat direduksi dalam hukum-hukum tunggal dan deterministik yang bebas konteks. Untuk menjelaskan gejala-gejala sosial tertentu tidak cukup mengamati dengan gejala-gejala yang tampak, tetapi dengan mempertimbangkan totalitas konteks dan lebih memperhatikan hubungan fungsional di dalam interaksi sosial (Sugiarti, 2013).

Selanjutnya, sastra tidak hanya memasuki ruang seluk-beluk dan nilai-nilai kehidupan personal, tetapi memasuki ruang dan seluk-beluk dan nilai-nilai kehidupan manusia dalam arti kosmopolit-total. Citra, cita-cita, dan perasaan yang tertuang dalam karya sastra terkadang dapat mewakili secara pas kerinduan batin manusia akan keadilan dan kemerdekaan sejati (Suyitno, 1986:5). Demikian kompleksitas nilai-nilai, citra, cita-cita, dan perasaan yang diungkapkan dalam sastra sehingga menjadikan karya sastra dibangun atas dasar rekaan. Selain itu, karya sastra dienergisasikan oleh imaji sehingga berhasil untuk mengevokasi kenyataan-kenyataan khususnya yang mengalami stagnasi sehingga tampil kembali ke permukaan sebagai aktualitas (Ratna, 2006:vi).

Proses kreativitas pengarang dalam melakukan pengembaraan batin melalui dunia realita sangat jeli dan mendalam. Segala sesuatu yang terjadi dalam kehidupan dijadikan pengalaman baru (new experience) pengarang dalam rangka mendalami, menghayati, dan mengimajinasi sebagai kekuatan untuk mengekplorasi pengalaman baru dan dunia baru. Semua itu merupakan respons atas berbagai fenomena kebudayaan masyarakat yang selalu terikat oleh nilai-nilai. Kesadaran terhadap nilainilai itu digunakan sebagai landasan kebudayaan di dalam hidup bersama. Kenyataan-kenyataan masyarakat dilahirkan oleh kebudayaan melalui penerapan ukuran-ukuran yang bersumber pada terhadap nilai-nilai (Sugiarti, 2011:190). Oleh karena itu, perlu kiranya memperkuat resistensi budaya bangsa kita atau semua itu sama artinya kita harus memperkuat identitas bangsa kita. Resistensi itu menunjukkan diri dalam perubahan dan perkembangan. Perkembangan itu kreatif, baru, dan tak terencana (Suseno, 1995:33).

Pada umumnya, latar belakang budaya berkaitan dengan asal sastrawan dilahirkan dan dibesarkan karena dari sanalah akar tradisi dan kebudayaan yang telah menyatu dalam dirinya menjadi sumber inspirasi yang tidak akan kering digalinya (Utomo, 2008). Subjek kreator berfungsi untuk menampilkan citra bahasa, menghidupkan makna wacana, dan memperjelas artikulasi sehingga terjadi koherensi antara karya sastra dengan latar belakang sosialnya, khususnya latar belakang produksi sastra (Ratna, 2011:139).

Indentitas dan etnisitas seseorang tidak hanya dapat diukur melalui kriteria tertentu yang pasti (secara objektif), tetapi juga harus diukur derajat perasaan kepemilikan (sense of belonging) akan kelompok etniknya (secara subjektif). Dalam perspektif itulah persoalan indentitas dan etnisitas itu sering timbul. Terbentuknya identitas etnik ternyata juga memerlukan kehadiran entitas atau etnik lain sebagai komparasi dan penegas identitas etnik yang bersangkutan. Hal itu menegaskan kembali bahwa identitas etnik merupakan hasil dari interaksi sosial. Kelompok yang tidak berinteraksi dengan kelompok lain mungkin tidak akan menyadari bahwa mereka 
memiliki kesamaan yang besar. Hanya dengan interaksi dengan kelompok lain identitas etnik mereka terbangun dan semakin intens interaksi itu serta semakin berkembang pula identitas etniknya (Danardana, 2012).

Tindakan kultural, konstruksi, pemahaman, dan penggunaan bentuk-bentuk simbol adalah peristiwa sosial seperti yang lainnnya semua itu berisifat publik (Geertz. 1992:6). Sejalan dengan pemikiran Taine (dalam Anwar, 2012:21) sifat karya sastra adalah dokumen pelengkap (furnished document) sebab karya sastra adalah sebuah monumen. Perbedaan periode sejarah dalam sastra justru menciptakan hubungan yang harmonis antara kecerdasan dan zaman. Pertama-tama sastrawan melakukan penetrasi kecerdasannya dalam memahami zaman dalam karya sastranya. Selanjutnya, sastrawan melakukan penetrasi yang lebih jauh ke dalam kecerdasannya memahami zaman dalam karya sastranya. Lebih lanjut dikatakan hanya sastrawan yang sungguh-sungguh besar sajalah yang menurut Taine mempunyai kapabilitas secara utuh untuk mengekspresikan zamannya dan merepresentasikan "modus" yang menjadi keseluruhan hati bangsa dan zamannya.

Representasi mengacu pada bagaimana seseorang, kelompok atau gagasan atau pendapat tertentu ditampilkan sebagaimana mestinya. Menurut Eriyanto (dalam Bardara, 2012:56) representasi penting dalam dua hal, apakah seseorang, kelompok, atau gagasan tersebut ditampilkan sebagaimana mestinya dan bagaimana representasi tersebut ditampilkan. Lebih lanjut Wibowo (2004:215) menegaskan bahwa representasi menunjuk pada dunia menampakkan diri tersebut dan menampakkan sebagai pertunjukkan bagi subjek penglihat atau subjek yang mengetahui.

Masalah yang nyata dan utama dalam tata adat kaum tampak begitu rumit untuk dipecahkan hanya oleh manusia biasa. Penyebabnya dalam novel menghadirkan juga tokoh-tokoh seperti bu Nian dan Sampiran, dua tokoh yang berasal dari dunia gaib (yang ternyata masuk dalam rumah Bagonjong), untuk membantu manusia mengetahui dan memecahkan masalahnya (Damono dalam Hadi, 2013:xv).

Karya sastra adalah anak kandung sastrawan yang akan menjadi yatim jika dia telah konkret berinteraksi dengan masyarakat. Sebagai "anak kandung" sudah jelas menggambarkan sifat-sifat derivasi sastrawan (selaku orang tua) dalam tubuh karya sastranya, betapa karya sastra tidak boleh disamakan secara mutlak dengan pembuatnya karena jelas tidak akan menemukan titik sepakat (Sugiarti, 1999:73). Demikian pula yang tautan peristiwa dalam novel Hadi pengarang sengaja menyajikan fenomena Minang dengan pernikperniknya sehingga Sapardi Djoko Damono dalam tulisan awal novel itu menuliskan Ensiklopedi Masalah Minang. Keyakinan tentang diri sendiri, kesadaran harga diri yang kuat, disertai keterbukaan, itulah yang dianggap sebagai sikap kritis Wisran dalam menghadirkan novel Hadi.

Keseluruhan upaya yang dilakukan tokohtokoh yang berasal dari dalam maupun luar kaum rumah Bagonjong, ternyata tidak menghasilkan pemecahan masalah. Sebagai bagian dari sindiran dan cemoohnya terhadap situasi itu, Wisran terus menerus memberikan pilihan bagi tokoh dalam bertindak dan si Bung juga diharapkan ikut "aktif" memberikan gagasan dan pilihannya. Si Bung boleh bingung sebab narator pun sebenarnya diberi tugas oleh pengarang untuk bingung menghadapi berbagai masalah yang timbul dan berkembang "hanya" gara-gara ulah Malati dengan guru agamanya (Damono dalam Hadi, 20113:xvi).

Dalam praktiknya persoalan di atas dapat diperhatikan melalui pada pendekatan sosio kultural terhadap sastra seperti yang diungkapkan Damono (1984:4-5) mengungkapkan bahwa (1) karya sastra tidak dapat dipahami secara selengkap-lengkapnya apabila dipisahkan dari lingkungan atau kebudayaan atau peradaban yang telah menghasilkannya. Dia harus dipelajari dalam konteks yang seluas-luasnya dan tidak hanya dirinya sendiri; (2) gagasan yang ada dalam karya sastra sama pentingnya dengan bentuk dan teknik penulisannya:, bahkan, boleh dikatakan bahwa bentuk dan teknik penulisannya ditentukan oleh gagasan tersebut; (3) setiap karya sastra yang bertahan lama pada hakikatnya adalah suatu moral, baik dalam hubungannya dengan kebudayaan maupun dalam hubungannya dengan orang- seorang; (4) masyarakat dapat mendekati karya sastra dari dua arah: pertama sebagai suatu kekuatan atau faktor material istimewa, dan kedua sebagai tradisi, yakni kecenderungankecenderungan spiritual maupun kultural yang bersifat kolektif.

Berdasarkan pemikiran di atas dapat diungkapkan bahwa pengarang/sastrawan dalam menghasilkan karya sastra selalu dikuti oleh roh waktu (spirit of time). Secara substansi perbedaan waktu akan menunjukkan perbedaan ide-ide 
dominan yang berisi pola intelektual yang memiliki relevansi dengan situasi dan kondisi zamannya

Secara operasional penelitian ini menggunakan pendekatan kualitatif. Di samping itu, dalam penelitian digunakan prinsip-prinsip metode analisis isi kualitatif yang biasa digunakan untuk memahami pesan simbolik dalam wacana.

Sumber data penelitian adalah novel Persiden karya Wisran Hadi. Data dalam penelitian ini berupa sekuen cerita yang memiliki relevansi dengan tujuan penelitian serta informasiinformasi penting yang diperoleh dari referensi. Selanjutnya untuk memudahkan pemahaman penelitian ini, peneliti menggunakan nama pengarang, tahun dan halaman untuk menandai bagian-bagian penting yang dikutip sesuai dengan fokus tulisan.

Analisis data penelitian ini menggunakan teknik (a) analisis isi (content analysis) dan (b) analisis interaktif-dialektis atau bolak-balik sesuai dengan keperluan penelitian. Di samping itu, perlu dilakukan penelaahan yang terkait dengan berbagai pemikiran pengarang dalam mengeksplorasi proses kreatif imajinatif melalui narasi cerita.

\section{Pembahasan}

Problematika persoalan identitas dan etnisitas menarik untuk dikaji secara mendalam. Novel sebagai salah satu produk kreatif pengarang tidak dapat dilepaskan dengan problematika persoalan itu. Wisran Hadi dalam novel Hadi mengungkapkan mindset masyarakat seputar rumah Bagonjong sebagai identitas masyarakat Minang. Secara keseluruhan pengarang mengeksplorasi bagaimana persoalan identitas dan etnisitas Minang dengan pernak-pernik persoalan yang dibalut dalam cerita sehingga memberikan informasi kepada pembaca.

\section{a. Bentuk Rumah Adat Minang}

\section{" Rumah bergonjong merupakan rumah adat yang harus dirawat dan dilestarikan keberadaannya oleh para generasi penerus kaum agar tidak hilang digilas zaman.}

Di antara peninggalan leluhur yang menjadi identitas sebuah kaum salah satunya adalah Rumah Bagonjong (sejenis Rumah Gadang) yang merupakan rumah adat dari Suku Minang khususnya mereka yang tinggal di Paratingga. Rumah Bagonjong menjadi identitas dan simbol bagi pemiliknya yang memiliki semangat tinggi dalam menghargai budaya. Oleh karena itu, pemerintah daerah setempat membuat kantor pemerintahan di Paratingga menjadi sebuah bangunan yang selalu memiliki gonjong (sisi kanan dan kiri atapnya menjulang tinggi di kanan serta runcing bagian atasnya). Hal itu dimaksudkan untuk menunjukkan bahwa penghuni bangunanbangunan bergonjong tersebut merupakan orangorang yang memiliki semangat dan budaya yang tinggi. Hal itu dapat dilihat pada kutipan berikut.

\section{Mungkin orang tidak peduli lagi dengan proporsi dan keindahan karena lebih mementingkan ciri. Jika sebuah bangunan diberi gonjong, itu sudah cukup dianggap sebagai tanda atau bukti dari adanya semangat yang tinggi dan kuat untuk berbudaya (Hadi. 2013:15).}

Rumah bergonjong merupakan rumah adat yang harus dirawat dan dilestarikan keberadaannya oleh para generasi penerus kaum agar tidak hilang digilas zaman. Untuk itu, dalam rangka melestarikan peninggalan leluhur, pemerintah daerah setempat membangun kantor pemerintah dengan menambahkan gonjong pada setiap atapnya. Hal itu tidak menciptakan kesan upaya pelestarian warisan, tetapi justru memberikan kesan bahwa daerah itu sedang dipimpin oleh pemerintah yang otoriter sehingga bentuk atap bangunan kantorpun harus diseragamkan.

Oleh karena kantor kepala daerah diberi atap bergonjong, maka hampir semua atap bangunan kantor dibuat bergonjong pula. Cara seperti ini dijadikan indikasi sebagai salah satu ciri dari sikap pemerintahan yang otoriter. Sampai kepada bentuk atapatap bangunan pun harus diseragamkan seperti bentuk atap bangunan kantor atasan (Hadi, 2013:15-16).

Perkantoran pemerintah yang meskipun memiliki atap yang berbentuk gonjong, belum dapat dikatakan sebagai Rumah Bagonjong yang menjadi identitas dari keturunan Angku Gonjong, sebab bangunan-bangunan milik pemerintah tersebut hanya wujud fisiknya yang menyerupai Rumah Bagonjong, tetapi tidak untuk nilai guna. Rumah Bagonjong yang sesungguhnya adalah sebuah rumah tua yang letaknya tidak 
terlihat sebab ditutupi oleh bangunan kantor pemerintahan. Rumah itulah sesungguhnya yang dapat dikatakan sebagai identitas kaum Paratingga.

Rumah tua yang terjepit oleh kedua gedung kantor itu dinamakan juga Rumah Bagonjong. Justru lebih dahulu rumah tua itu dinamakan demikian daripada kantor kepala daerah, walau bentuk dan ukurannya bukanlah sebentuk dan seukuran rumah Bagonjong atau rumah gadang yang umum dikenal (Hadi, 2013:17).

Rumah adat yang disebut dengan Rumah Bagonjong sebenarnya merupakan rumah warisan leluhur. Kaum yang tinggal di Paratingga merupakan keturunan dari Angku Gonjong (ketua kaum) yang menamakan rumah itu menjadi Rumah Bagonjong. Jika mereka adalah pewaris, keturunan mereka yang berkewajiban untuk tetap menjaga keberadaan rumah bersejarah tersebut.

Rumah Bagonjong itu bukanlah rumah gadang dalam pengertian umum. Konon, rumah ini pengganti rumah gadang yang dahulu pernah berdiri di situ. Atau, mungkin sekali nama Rumah Bagonjong itu berasal dari nama salah seorang kepala kaum mereka; Angku Gonjong (Hadi, 2013:17).

Orang Paratingga sebenarnya tidak berhak menganggap Rumah Bagonjong sebagai milik pribadi mereka. Rumah tersebut bukan didirikan oleh mereka yang masih hidup saat ini. Rumah Bagonjong dibangun oleh ayah dari kakek mereka yang saat itu masih hidup. Rumah Bagonjong tersebut sebenarnya adalah rumah bersama dan rumah adat dari leluhur nenek moyang keturunan Angku Gonjong sehingga rumah Bagonjong sebenarnya adalah milik kaum Rumah Bagonjong.

\section{b. Prinsip Hidup dalam Menyikapi Warisan Budaya Leluhur}

"Rumah Bagonjong yang sesungguhnya adalah sebuah rumah tua yang letaknya tidak terlihat sebab ditutupi oleh bangunan-bangunan kantor pemerintahan. "
Usia Rumah Bagonjong sangat tua, bangunan tersebut sudah rapuh di segala sisinya. Kerapuhan tersebut bukan hanya terjadi pada Rumah Bagonjong, melainkan juga terjadi pada rumahrumah tua yang ada di sekelilingnya. Rumah-rumah adat tersebut semakin lama semakin mendekati kehancuran, sebab para pewarisnya tidak memiliki niat untuk memperbaikinya. Rumah peninggalan tersebut merupakan identitas dari kaum mereka.

Di Rumah Bagonjong itulah ayah Bung, ayah Bang Samu, dan dua saudaranya yang lain dilahirkan. Rumah itu sendiri didirikan oleh ayah mereka, atau kakek Bung. Jadi jika dilihat dari secara hukum adat Paratingga, Rumah Bagonjong bukanlah milik kaum dari ayah Bung. Namun karena rumah itu didirikan di atas tanah kaum ayah Bung, maka rumah itu dianggap sebagai milik kaum ayah Bung. Semakin bertambah umur penghuninya, rumah itupun semakin lapuk. Rumah-rumah penduduk sekitar Rumah Bagonjong bernasib sama. Tidak ada usaha untuk memperbaiki (Hadi, 2013:18).

Orang Paratingga yang memiliki warisan berupa rumah adat seperti Rumah Bagonjong, tidak merasa perlu untuk menjaga kelestarian peninggalan bersejarah tersebut. Mereka lebih memilih untuk membangun rumah dengan jerih payah sendiri daripada harus memperbaiki rumah usang, meskipun rumah baru yang didirikannya itu bentuk dan ukurannya lebih buruk dari rumah warisan leluhur mereka.

Hal inilah identitas dari karakter orang Paratingga. Sesuatu akan dirasa lebih berharga jika dapat diperoleh dengan kekuatan sendiri daripada yang hanya merupakan hasil warisan.

Orang-orang Paratingga umumnya tidak mau memperbaiki rumah usang. Lebih baik mereka mendirikan rumah sendiri walau ukuran dan bentuknya sangat sederhana. Mereka berusaha untuk memiliki rumah sendiri bagaimanapun kondisinya (Hadi, 2013:18).

Karakter lain yang menjadi identitas dari etnik Paratingga adalah tidak dimilikinya rasa bangga terhadap peninggalan nenek moyangnya, yakni rumah yang memiliki ukuran besar. Mereka lebih bangga jika memiliki rumah yang dibangun atas hasil usaha mereka, bukan rumah warisan betapapun besarnya. Alasan ketidakbanggaan mereka adalah, rumah warisan sering menjadi sumber pertengkaran dan perpecahan antarsaudara sebab saling berebut untuk 
memilikinya

Mereka tidak bangga dengan rumah besar yang ditinggalkan nenek moyangnya karena rumah warisan nenek moyang umumnya selalu menjadi biang pertengkaran sesama saudara (Hadi, 2013:18).

Identitas lain yang dominan ada pada orang Paratingga adalah kegigihannya dalam mewujudkan sesuatu yang kelak akan menjadi milik mereka seutuhnya. Hal itu dapat dilihat dari sikap mereka yang lebih memilih tinggal dan hidup pada sebuah bangunan yang kecil meskipun harus berdesak-desakkan daripada harus menerima dan merawat rumah besar yang merupakan warisan dari nenek moyang mereka. Mereka bersemboyan bahwa masa lalu adalah milik masa lalu, bukan milik masa kini maupun masa depan. Oleh karena itu, mereka menganggap bahwa Rumah Bagonjong merupakan rumah nenek mereka dan bukan rumah milik pribadi. Hal itu sangat berbeda dengan prinsip kaum lain yang tinggal di kampung sekeliling Paratingga.

Lebih baik tinggal pada sebuah bilik kecil, berdesak-desak, tetapi dibangun atas jerih payah sendiri. Sifat orang Paratingga demikian sangat berbeda dengan sifat orang di kampung lain dalam mempertahankan adat budaya. Jika orang lain berbangga-bangga dengan peninggalan masa lalu sehingga mereka perlu mempertahankan dan menjaga semua warisan nenek moyang agar tidak punah, seperti gonjong atap rumah gadang yang dijadikan atap perkantoran misalnya, maka orang Paratingga tidak demikian. Bagi mereka masa lalu adalah masa lalu. Rumah Bagonjong warisan nenek adalah milik nenek, bukan milik pribadinya sendiri (Hadi, 2013:18-19).

Di antara sikap dan karakter yang berbeda dari orang Paratingga adalah sikap dan karakter keturunan Angku Gonjong, yang disebut dengan kaum Rumah Bagonjong, meskipun mereka juga tinggal di Paratingga. Mereka masih berusaha untuk merawat peninggalan bersejarah dari leluhur mereka. Keturunan Angku Gonjong saat ini yang menguasai Rumah Bagonjong terdiri atas lima orang yang disebut kaum Rumah Bagonjong, dan kelima-limanya memiliki alasan tersendiri untuk mempertahankan rumah tersebut. Tiba saatnya pada suatu ketika, Rumah Bagonjong dibiarkan tidak terawat dan tidak berpenghuni. Hal itu dikarenakan oleh sebuah alasan yang hanya diketahui oleh mereka masing-masing.
Lain halnya dengan Rumah Bagonjong, rumah asal tempat kelahiran ayah Bung. Ayah Bung bersama keempat saudaranya masing-masing punya alasan tersendiri untuk menjaga dan memelihara Rumah Bagonjong. Bagaimana mereka mempertahankan Rumah Bagonjongnya sampai akhirnya rumah itu tidak dihuni lagi adalah akibat dari cara yang tidak pernah dapat diseragamkan (Hadi, 2013: 19).

Ketika Rumah Bagonjong tidak lagi dihuni dan dirawat oleh ahli warisnya (kaum Rumah Bagonjong), satu-satunya orang yang masih sering masuk dan menggunakan Rumah Bagonjong sebagai tempat istirahat adalah Bang Samu, yakni cucu dari kaum Angku Gonjong. Orang Paratingga menganggap wajar apa yang dilakukan oleh Bang Samu, sebab yang melakukannya masih ahli waris dari Rumah Bagonjong tersebut.

Orang-orang Paratingga menganggap Bang Samu sebagai salah seorang cucu dari Angku Gonjong. Siapa yang berhak melarang cucu Angku Gonjong tidur dan bermain di rumah kaum Angku Gonjong sendiri? Dengan anggapan demikian, Bang Samu merasa mendapat kebebasan penuh berada di rumah warisan kakeknya (Hadi, 2013:20).

\section{c. Pemakaian Sebutan dalam Silsilah Keluarga}

Pemberian sebutan yang dilekatkan kepada diri seseorang akan menjadi identitas yang menunjukkan status orang tersebut. Begitu juga pemberian sebutan dalam silsilah kekerabatan. Setiap etnis (suku bangsa), memiliki adat budaya yang beragam dalam pemberian sebutan terhadap diri seseorang yang masih memiliki hubungan kekeluargaan. Salah satu di antara etnis/kaum yang memiliki ciri khas dalam penyebutan seseorang yang masih memiliki hubungan darah adalah kaum Rumah Bagonjong dan juga orangorang Paratingga.

Kaum Rumah Bagonjong dan orang Paratingga memiliki sebutan yang berbeda terhadap orang yang masih berkerabat dengan mereka. Saudara laki-laki dari lbu mereka memiliki sebutan yang berbeda dengan saudara laki-laki dari ayah mereka. Hal itu tidak dapat dibolak-balik sebab sudah menjadi hukum adat di antara orang Paratingga.

Saudara laki-laki dari ibu harus dipanggil dengan sebutan "pa", baik yang berkedudukan 
sebagai kakak maupun adik dari ibu. Sementara itu, saudara laki-laki dari ayah, baik yang berkedudukan sebagai adik maupun kakak harus dipanggil dengan sebutan "ma" yang merupakan kependekan dari kata "mamak". Dengan adanya perbedaan dalam penyebutan kerabat, status kekerabatan akan tetap terjaga. Sebutan tersebut dilekatkan atas dasar status fungsional yang melekat pada identitas kerabat tersebut.

Adik bungsu ayah Bung namanya Ramawan "Pa Rarau". Memanggilnya harus "Pa Rarau", bukan "Pak Rarau", walau ucapan "pa" ditulis "pak". Tulisan dari kata "pak" diucapkan dengan bunyi "pa" itu kependekan dari bapak karena statusnya memang bapak. Dia adik dari bapak. Jadi, panggilan "pa" dalam hal ini bukan hanya untuk pengormatan atau kelatahan saja, melainkan fungsional, menjelaskan status (Hadi, 2013: 23).

Kutipan berikut, juga menjadi bukti adanya perbedaan pemberian sebutan kepada kerabat yang berasal dari ibu dan juga yang berasal dari ayah.

Lain halnya saudara laki-laki dari Ibu, tidak boleh dipanggil begitu. Mereka bukan dari pihak bapak. Saudara laki-laki dari ibu harus dipanggil "ma" bila dituliskan menjadi "mak" berasal dari kata "mamak". Jangan dicampuradukkan antar memanggil "pa" untuk saudara ayah dengan "ma" untuk saudara ibu (Hadi, 2013:23)

Orang Paratingga sangat protektif mengenai budaya penyebutan seseorang. Sebagai contoh pada sebutan "pa". Sebutan "pa”, bagi mereka hanya boleh digunakan untuk memanggil kerabat laki-laki dari silsilah ayah, dan tidak boleh digunakan dalam menyebut orang lain. Pada saat ini, sebutan "pa" telah banyak dilekatkan pada siapapun yang memiliki usia ataupun kedudukan yang lebih tinggi daripada yang menyebut. Hal ini bagi kaum Paratingga merupakan pelanggaran hukum adat. Oleh karena itu, jika ada orang lain yang memanggil seseorang dari Paratingga dengan sebutan "pa", sesegera mungkin orang yang dipanggil tersebut akan memberikan pertanyaan yang pada hakikatnya tidak membutuhkan jawaban, tetapi hanya untuk mengingatkan bahwa panggilan tersebut tidak sesuai dengan status fungsional orang tersebut. Sebagai contoh dapat dilihat pada kutipan berikut.

Sekarang ini, seorang laki-laki yang bukan bapak kita juga sering dipanggil "pa". Jika panggilan itu diucapkan pada laki- laki Paratingga, maka dia akan segera membalas dengan mencomooh, "Kapan saya nikah dengan ibumu?" atau "Aku tidak pernah jadi saudara ayahmu." Oleh karena itu, jika memanggil seseorang harus hatihati (Hadi, 2013:24).

Sebutan yang dilekatkan kepada Kinan (anak perempuan satu-satunya yang menguasai Rumah Bagonjong) dengan sebutan "ci" mengandung arti kakak. Akan tetapi, sebutan tersebut tidak lekas dapat diganti dengan sebutan yang lain, misalnya saja "tante", sebab sebutan "tante" tidak dikenal oleh orang Paratingga. Sebagai dampak dari penyebutan "tante" tersebut, siapapun yang menggunakannya tidak akan diakui sebagai orang Paratingga tetapi sebagai orang kota.

Tidak demikian halnya dengan yang telah dilakukan $\mathrm{Ci}$ Inan. Adik perempuan ayah Bung itu selalu dipanggil "Ci Inan" baik oleh orang tua, muda, maupun anak-anak. Secara tertulis panggilan itu Cik Kinan karena nama lengkapnya Kinan. Kata "cik" yang dibaca "ci" sama artinya dengan kakak atau uni. Jangan dipanggil "tante". Apabila terdengar oleh orang Paratingga yang suka mencemooh itu kalau Bung memanggil "tante" padanya, mereka akan mengatakan Bung bukan orang Paratingga, melainkan "orang kota" (Hadi, 2013:3839).

Kaum Paratingga lebih suka menggunakan bahasa mereka sendiri meskipun dianggap kaum lain kurang mengikuti kemajuan zaman. Akan tetapi, bagi kaum Paratingga, menggunakan bahasa sendiri justru lebih baik daripada menggunakan bahasa kaum lain, tetapi tidak sesuai dengan hati sendiri. Mempertahankan identitas bahasa yang merujuk pada etnisitas menjadi penting bagi masyarakat Paratingga.

Oleh sebab rasa bahasa yang berbeda itulah, orang Paratingga lebih suka memakai bahasanya sendiri daripada memakai yang baru tetapi tidak sesuai dengan rasa bahasa yang dimilikinya (Hadi, 2013:39).

Bagi orang-orang Paratingga, khususnya keturunan Angku Gonjong, menertibkan panggilan dengan sebutan tertentu akan turut menjaga dan melestarikan adat istiadat dan juga tata nilai dalam masyarakat. Nama panggilan bagi etnis Minang bersifat fungsional karena memiliki keterkaitan dengan pranata sosial masyarakat.

Panggilan-panggilan itu perlu ditertibkan kembali karena termasuk bagian dari tata 
nilai, tata cara, dan adat istiadat yang masih dimiliki sampai sekarang ( Hadi, 2013:24).

\section{d. Pembagian Hak atas Warisan Budaya Leluhur}

Salah satu identitas yang dimiliki orang Paratingga adalah masalah keadilan dalam pembagian warisan leluhur. Sebagai ahli waris dari Rumah Bagonjong, kelima bersaudara keturunan Angku Gonjong memiliki hak yang sama atas rumah tersebut. Pada kenyataannya, dari lima bersaudara tersebut ada yang merasa tidak lagi memiliki hak tersebut. Hal ini dikarenakan perselisihan paham yang terjadi antar lima bersaudara tersebut, yakni antara Pa Rarau dan Pa Mikie dengan $\mathrm{Ci}$ Inan (saudara perempuan satu-satunya yang akan menjadi penerus keturunan di Rumah Bagonjong).

Padahal, baik secara adat apalagi turunan darah, Pa Rarau punya hak sama seperti keempat saudarnya yang lain. Seandainya Rumah Bagonjong itu dibagi menurut hukum waris secara Islam, dia semestinya juga mendapat bagian (Hadi, 2013:27).

Saudara perempuan dalam hukum adat orang-orang Paratingga merupakan penerus keturunan dari sebuah kaum. Menurut hukum adat orang Paratingga, saudara perempuan jugalah yang berhak merawat dan menempati Rumah Bagonjong yang merupakan warisan leluhur. Orang-orang Paratingga baru akan dikatakan memiliki keturunan jika memiliki saudara perempuan.

Ternyata sekarang Rumah Bagonjong itu dikuasai oleh saudara perempuan mereka, Ci Inan. Saudara perempuan satu-satunya yang diharapkan dapat menjadi pengikat dan pautan hati untuk selalu mengenang kehidupan di Rumah Bagonjong (Hadi, 2013:27).

Keberadaan Rumah Bagonjong yang merupakan rumah tua dan mengandung sejarah, sedapat mungkin akan dipertahankan oleh kaum Rumah Bagonjong. Tetapi hal itu tidak sealur dengan keinginan pemerintah kota. Petugas tata kota senantiasa mendesak kaum Rumah Bagonjong untuk menggeser atau merobohkan rumah tersebut sebab tidak sesuai dengan tata kota yang ada saat itu. Desakan tersebut oleh kaum Rumah Bagonjong dianggap sebagai upaya buruk orang-orang yang tidak menyukai adanya Rumah Bagonjong yang masih dipertahankan hingga saat ini.
Namun, setelah waktu berjalan dan banyak persoalan yang terjadi sesudahnya, desakan petugas tata kota mereka anggap saja sebagai usaha pihak lain yang mau meruntuhkan Rumah Bagonjong, orangorang lain yang tidak menyukai adanya rumah-rumah tua yang mengandung sejarah kebanggaan suatu kaum atau kampung (Hadi, 2013:28).

\section{e. Prinsip Hidup dalam Menyikapi Rasa Malu}

Salah satu identitas dari orang-orang Paratingga adalah prinsip dan sikap mereka dalam menyikapi rasa malu. Mereka merupakan orangorang yang mudah melupakan rasa malu yang menghinggapinya. Mereka menganggap rasa malu hanya datang sesaat. Jika sebuah rahasia yang dapat menyebabkan rasa malu terbongkar, mereka akan segera melupakan rasa malu itu. Kemudian jika orang-orang Paratingga sudah tidak mampu menghindari malu, mereka akan berubah menjadi pemaaf, yakni memaafkan sesuatu yang menyebabkan rasa malu itu menghinggapi.

Rasa malu hanya datang sesaat, tidak terus menerus. Apalagi orang-orang Paratingga. Mereka cepat lupa dengan malu. Cepat lupa dengan rahasia-rahasia lainnya yang kalau terbongkar dapat membuat mereka malu. Bila tidak mampu mengatasi suatu situasi atau keadaan untuk menghindari malu, mereka langsung jadi pemaaf. Mereka maafkan semua yang terjadi, apapun bentuknya dan betapapun rasa malunya (Hadi, 2013:37).

Hal lain yang bertolak belakang dengan prinsip yang pertama tadi, jika mereka memiliki kemampuan menguasai keadaan yang menyebabkan mereka malu, mereka akan bersikukuh mengusut penyebab rasa malu tersebut hingga tuntas. Pembuat malu harus mendapat hukuman atau ganjaran.

Namun, kalau dapat menguasai keadaan atau sedikit saja mendapat angin, hal yang menyebabkan mereka menjadi malu, pasti akan diusut sampai tuntas. Mereka akan mengatakan bahwa sesuatu yang menjadi sebab terjadinya malu haus mendapat ganjaran atau hukuman (Hadi, 2013:37).

Bagi masyarakat Paratingga, sedapat mungkin mereka menghindari sesuatu yang dapat menyebabkan rasa malu. Malu adalah sebuah aib yang pantang dialami oleh kaum mereka. 
"Rahasia suatu kaum tidak akan dibongkar oleh kelompok kaum itu sendiri karena itu persoalan besar. Dalam pandangan masyarakat umum bahwa rahasia itu bukanlah rahasia tetapi dengan sengaja ditutup-tutupi.

Apapun risikonya, malu harus ditebus dan harus dipertanggungjawabkan.

\begin{abstract}
Menurut ajaran tradisinya, orang-orang Paratingga tidak boleh mendapat malu, walau apapun sebabnya. Malu adalah aib. Malu harus ditebus betapapun mahalnya. Namun dalam keadaan seperti sekarang, saat-saat tidak dapat berbuat apa-apa baik karena kemiskinan maupun kesulitan hidup, mereka tidak punya kekuatan menguasai keadaan (Hadi, 2013:38).
\end{abstract}

Identitas lain yang menunjukkan keetnisan orang Paratingga adalah pantangan mereka untuk tidak menyembunyikan persoalan pribadi yang sebenarnya sudah menjadi rahasia umum. Hal itu justru akan memperbesar rasa malu yang akan ditanggungnya jika persoalan tersebut terbongkar.

\begin{abstract}
Menyembunyikan persoalan yang sudah menjadi rahasia umum, sebenarnya akan semakin memperbesar rasa malu sekiranya kelak terbongkar. Seharusnya persoalanpersoalan yang dapat menimbulkan malu diungkap saja secara terbuka. Untuk apa ditutup-tutupi kalau memang tidak mungkin dapat ditutupi (Hadi, 2013:38).
\end{abstract}

Pantangan bagi orang Paratingga adalah tidak diperkenankan menyembunyikan persoalan yang sudah diketahui umum. Hal itu justru tidak berlaku pada diri Ci Inan dan keluarganya. Mereka bertekad untuk tetap merahasiakan persoalan mereka yang jika diungkapkan akan mendatangkan rasa malu yang luar biasa.

Akibat dari tekadnya yang gigih untuk tetap merahasiakan persoalan keluarganya dari kakak dan adik-adiknya, Ci Inan merasa resah. Biasanya jika seseorang telah menyembunyikan sebuah rahasia, orang Paratingga akan segera berkasakkusuk dan saling berbisik, tetapi hal tersebut tidak terjadi pada kasus Ci Inan. Tidak ada desasdesus ataupun bisik-bisik dari orang sekitar. Hal itu membuat Ci Inan was-was, jangan-jangan mereka diam karena sudah tidak peduli lagi dengan Ci Inan dan keluarga sehingga mereka malas untuk hanya sekadar bergosip tentangnya.
Namun di sisi lain dengan tidak adanya orang-orang yang berbisik-bisik, berkemungkinan orang sudah melupakan hal yang mereka ketahui terhadap sesuatu yang dirahasiakannya. Dari satu sisi, hal ini sangat baik baginya. Rahasia akan tetap menjadi rahasia. Namun, dari sisi lain, dengan tidak adanya orang yang berbisik-bisik atau orang telah benar- benar melupakan persolannya, justru dirinya merasa tidak diacuhkan lagi. Tidak disiapa-siapakan lagi oleh masyarakat. Hal semacam ini lebih menyakitkan karena orang tidak menganggapnya apa-apa lagi. Untuk apa hidup dalam sebuah masyarakat kalau kita tidak diapa-siapakan lagi (Hadi, 2013:40).

Di antara identitas lain yang melekat pada orang Paratingga adalah bahwa setiap orang di Paratingga merasa tahu atas segala permaslahatan yang dialami oleh orang-orang di sekitarnya. Rahasia suatu kaum tidak akan dibongkar oleh kelompok kaum itu sendiri karena itu persoalan besar. Dalam pandangan masyarakat umum bahwa rahasia itu bukanlah rahasia, tetapi dengan sengaja ditutup-tutupi. Sebagian besar masyarakat Paratingga tidak ada yang berani membuka rahasia yang dialami oleh keluarga kaum. Masyarakat masih memberikan penghargaan terhadap kelompok komunitas kaum rumah Bagonjong Di sinilah keunikan hidup dalam masyarakat
Paratingga. Setiap orang merasa tahu
segala persoalan dan juga merasa tidak
tahu tentang persoalan itu secara lengkap.
Setiap orang merasa malu kalau sebuah
rahasia terbongkar. Padahal rahasia itu
bukan lagi rahasia karena semua orang
sudah membicarakannya (Hadi, 2013: 41-
42)

\section{f. Kedudukan Suami sebagai pembuat Keturunan dalam Kaum/Suku}

Jika pada masyarakat Jawa, suami adalah segala-galanya dalam sebuah keluarga. Hal tersebut tidak berlaku pada orang Paratingga (Minang). Hukum adat mereka menganggap seorang suami atau ipar (suami dari saudara perempuan), hanyalah sebagai pajangan. Suami 
tidak lebih dari mesin pencetak keturunan belaka. Dengan demikian, seorang suami dari saudara perempuan tidak memiliki hak apa-apa dalam urusan kaum istrinya, tetapi hal tersebut juga tidak diindahkan oleh Pa Lendo (suami Ci Inan).

\begin{abstract}
Orang-orang Paratingga sudah lama mengetahui tindak-tanduk $\mathrm{Pa}$ Lendo sebagai semenda. Seharusnya seorang suami tidak boleh ikut dalam persoalan kaum istrinya. Persoalan-persoalan di dalam kaum harus diselesaikan oleh itu sendiri. Namun $\mathrm{Pa}$ Lendo merasa perlu ikut campur karena menganggap semua persoalan menyangkut masalah keselamatan istri dan anaknya. Semua persoalan ingin diketahuinya, bahkan ikut pula memberi pendapat, kritik, dan arahan. Suatu hal yang pantang bagi suatu kaum, kalau ada orang lain di luar kaum yang ikut-ikutan dalam persoalan mereka. "Kereta api yang mendaki, kenapa dia yang sesak napas?" bisik mereka kesal bila semenda yang selalu akan menyembelih orang itu marah-marah (Hadi, 2013:46).
\end{abstract}

Dalam hukum adat orang-orang Paratingga, jika saudara perempuan ada yang bercerai dengan suaminya, yang bertanggung jawab terhadap kelangsungan hidup saudara perempuan tersebut adalah saudara laki-lakinya. Mereka berkewajiban memberikan biaya hidup dan juga mengambil alih segala hal yang berhungan dengan kemenakannya (anak-anak dari saudara perempuan tersebut).

Sebab jika perceraian itu terjadi, yang akan menanggung akibatnya bukan hanya $\mathrm{Ci}$ Inan sendiri, melainkan juga mereka berempat. Akan menjadi beban bagi $\mathrm{Pa}$ Tandang sebagai kakak tertua. Keempat saudara laki-laki harus mengambil tanggung jawab membiayai kehidupan $\mathrm{Ci}$ Inan beserta anak-anaknya (Hadi, 2013:47).

Hukum adat orang-orang Paratingga juga menyatakan bahwa saudara laki-laki harus mengambil alih tanggung jawab yang pada awalnya menjadi tanggung jawab suami. Dalam hukum adat dijelaskan, bahwa saudara perempuan adalah penentu garis keturunan suatu kaum.

Adat mengajarkan kepada mereka bahwa saudara laki-laki harus bertanggung jawab terhadap keselamatan dan kelangsungan hidup saudara perempuan beserta anakanaknya, karena dari perempuan itulah garis turunan serta pewarisan harta pusaka ditentukan (Hadi, 2013:47).

Sebagai seorang paman (dalam istilah etnis Minang disebut mamak sebab berasal dari silsilah ibu), mereka harus menanggung beban biaya untuk keberlangsungan hidup saudara perempuannya yang diceraikan oleh suaminya. Oleh karena itu, orang Paratingga menganggap bahwa sistem adat di tanah kelahiran mereka bertumpu pada keberlimpahan harta dan benda. Siapa pun yang tidak berlimpahan harta, sulit untuk menegakkan hukum adat.

"Menurut adat, kita adalah mamak dari
anak-anak Ci Inan. Kita harus bertanggung
jawab. Namun kalau mamak miskin,
bagaimana bisa membiayai kemenakan?
Sistem adat kita berpunca pada materi.
Kalau mau beradat harus kaya", kata
Pa Tandang terkekeh-kekeh dalam
perdebatannya dengan Pa Rarau (Hadi,
2013: 50).

Kehamilan Malati (anak perempuan dari Ci Inan) yang terjadi di luar nikah telah benarbenar menghancurkan nama baik kaum Rumah Bagonjong. Bagaimana mungkin, kaum Rumah Bagonjong yang ketaatannya pada Tuhan sangat tinggi menjadi pembela seseorang yang melakukan perzinaan. Hal itu dikarenakan kedua orang tua Malati yang tidak lain adalah $\mathrm{Ci}$ Inan, sengaja menutupi persoalan tersebut dari sepengetahuan adik dan kakak-kakaknya. Malati dianggap telah mendatangkan rasa malu pada seluruh kaum Rumah Bagonjong. Oleh karena itu, Malati harus menebus kesalahan tersebut dengan apapun risikonya.

Malati telah mencorengkan arang di dahi semua keluarga Rumah Bagonjong, baik yang masih hidup, sudah mati, atau yang akan lahir kemudian. Belum pernah terjadi di dalam kaum keluarga Rumah Bagonjong kejadian yang begitu memalukan. Malu harus ditebus. $\mathrm{Ci}$ Inan dan suaminya harus bertanggung jawab (Hadi, 2013:64)

Bagi kaum Bagonjong masih menghargai adanya norma agama terkait dengan pergaulan antara laki-laki dan perempuan. Apabila nilai-nilai tersebut dilanggar, secara tidak langsung akan memperoleh sangsi sosial dalam masyarakat. Seperti kerahasiaan kehamilan Malati oleh kedua orang tuanya. Hal tersebut dianggap suatu pembelaan terhadap perzinahan. Keluarga Malati tidak mau berterus terang terhadap masyarakat atau setidaknya kepada kaum Rumah Bagonjong atas kesalahan yang dilakukan oleh anak perempuan tersebut. Jika kehamilan Malati yang terjadi secara tidak wajar tetap didiamkan, hal itu menandakan bahwa kaum Rumah Bagonjong juga ikut melakukan pembelaan terhadap perzinahan 
yang dilakukan Malati, hingga akhirnya nanti, ditakutkannya semua keturunan Rumah Bagonjong akan selalu membela dan membenarkan sebuah perzinaan.

Secara lebih jelas, dikatakan Pa Mikie bahwa Ci Inan dan suaminya telah membenarkan perzinaan terjadi di dalam keluarga Rumah Bagonjong. Hal ini sangat berbahaya. Kelak semua anak-anak dan keturunan Rumah Bagonjong akan membenarkan perzinaan, dan orang-orang akan menuding mereka sebagai keluarga pezina (Hadi, 2013:64).

Dalam tradisi kehidupan masyarakat Minang, saudara laki-laki dari silsilah ibu menurut hukum adat kaum Rumah Bagonjong harus bertangung jawab penuh terhadap segala sesuatu yang berkaitan dengan kemenakan yang berasal dari saudara perempuan mereka. Oleh karenanya, urusan Malati yang merupakan anak dari $\mathrm{Ci}$ Inan, saudara perempuan satu-satunya dalam Rumah Bagonjong seharusnya menjadi urusan mamak-mamaknya. Jika Malati akan menikah, segala urusan dan putusan terhadap pernikahan Malati menjadi tanggung jawab mamaknya bukan tanggung jawab Pa Lendo meskipun dia adalah ayah Malati. Demikian hukum adat yang harus diikuti oleh keturunan kaum Rumah Bagonjong.

\begin{abstract}
Khusus bagi Pa Lendo, sebagai semenda dia telah menghancurkan tatanan adat di dalam kaum istrinya sendiri. Malati atau siapa saja anak yang lahir dari rahim $\mathrm{Ci}$ Inan mutlak menjadi kemenakan dari mamak-mamaknya. Kemenakan bagi $\mathrm{Pa}$ Mikie dan ketiga saudaranya. Jika ada suatu rencana pernikahan dari kemenakan itu, maka semua perencanaan dan putusannya berada dalam tangan Pa Mikie dan saudara-saudaranya sebagai mamak. Mamaknyalah yang berkuasa atas anakanak Ci Inan, bukan Pa Lendo, walau bagi Malati ayah sendiri (Hadi, 2013:65).
\end{abstract}

Hukum adat yang secara turun-temurun dipatuhi oleh kaum Rumah Bagonjong dan menjadi kacau balau tatanannya sebab ulah dan kelakuan Pa Lendo, ayah Malati. Sebagai seorang suami dari saudara perempuan kaum Rumah Bagonjong, seharusnya Pa Lendo memosisikan dirinya sebagai orang luar kaum yang tidak memiliki hak untuk mencampuri segala permasalahan kaum istrinya. Hal itu disebabkan bahwa seorang semenda sebenarnya hanya berfungsi sebagai pajangan dan mesin pembuat keturunan.

Pa Lendo hanya seorang semenda, tamu, bibit, agar Ci Inan dapat mengandung dan melahirkan keturunan Rumah Bagonjong berikutnya. Seorang semenda yang penting adalah spermanya. Semenda itu sperma. Semenda tanpa sperma, sama halnya menikahkan saudara perempuan kita dengan batang pisang. Tidak akan dapat menghasilkan keturunan (Hadi, 2013:65).

Sebagai orang yang berada di luar kaum, Pa Lendo sama sekali tidak memiliki hak apapun terhadap urusan kaum istrinya. Tradisi Rumah Bagonjong mengibaratkan bahwa seorang semenda tidak lebih dari debu yang hanya mampu menempel pada suatu benda, tetapi tidak dapat masuk di dalam tubuh benda tersebut. Hal itu yang menjadi salah satu identitas keetnikan dari kaum Rumah Bagonjong.

Di dalam adat di katakan, semenda itu hanyalah debu. Debu di atas tunggul. Debu tidak akan dapat lengket di atas tunggul. Debu tidak tidak akan dapat lengket di atas tunggul. Debu tidak dapat membongkar tunggul sekiranya di tiup angin. Debulah yang akan hilang di udara jika ditiup angin. Menurut $\mathrm{Pa}$ Mikie, perusakan tatanan adat sebuah kaum yang dilakukan oleh orang luar kaum, sama halnya dengan menelanjangi kaum itu sendiri (Hadi, 2013:65).

Sebagai bentuk pertanggungjawaban dari kehamilan dan pernikahan Malati yang disembunyikan dari kaum Rumah Bagonjong, Ci Inan dan Pa Lendo harus dihukum sesuai dengan hukum adat yang berlaku, yakni dibuang atau diusir dari tanah atau kampung kaum Rumah Bagonjong.

Malati beserta ayah ibunya harus dihukum sesuai dengan sanksi adat yang masih berlaku. Ketiganya harus dibuang, diusir dari rumah Bagonjong. Rumah pusaka yang suci itu tidak boleh dikotori siapapun. Silahkan cari kampung, negeri, atau rumah yang lain (Hadi, 2013:66).

Sebagai keturunan kaum Rumah Bagonjong, seharusnya Ci Inan dan Pa Lendo berterus terang terhadap kaum Rumah Bagonjong yang lain atas kehamilan dan pernikahan Malati. Dengan demikian, ditemukan solusi yang tepat untuk bermusyawarah antarkaum rumah Bagonjong. Akan tetapi, yang dilakukan oleh $\mathrm{Ci}$ Inan dan $\mathrm{Pa}$ Lendo justru sebaliknya. Mereka menyembunyikan persoalan tersebut dan mengungsikan Malati ke tanah orang hingga anaknya lahir. Setelah itu memindahkan Malati ke Yogyakarta serta memisahkan Malati dengan anak dan suaminya 
terlebih dahulu. Bayi yang telah dilahirkan Malati langsung diserahkan $\mathrm{Ci}$ Inan kepada orang tua suami Malati. Dengan tindakan yang demikian, $\mathrm{Ci}$ Inan dan $\mathrm{Pa}$ Lendo telah melanggar dua hukum, yakni hukum adat dan hukum agama.

Kalianlah penanggung jawab keluarga Rumah Bagonjong. Dia harus mengatakan secara terus terang. Ingat, Kie. Mamak urusannya bukan hanya mengurus dan mengatur harta pusaka saja, tetapi juga bertanggung jawab terhadap moral dan etika kaumnya. Persoalan Malati telah melanggar dua hal penting. Adat dan agama (Hadi. 2013: 104)

Identitas lain dari etnik Rumah Bagonjong yang tinggal di Paratingga adalah mementingkan garis keturunan dari silsilah perempuan. Bagi kaum Rumah Bagonjong, saudara perempuan adalah segala-galanya. Saudara perempuan itulah yang akan melanjutkan keturunan mereka. Jika dalam sebuah kaum tidak memiliki saudara perempuan, kaum tersebut dinyatakan punah karena tidak ada yang akan meneruskan keturunan kaum tersebut.

Jika suatu kaum tidak punya keturunan perempuan, berarti kaum itu punah, tidak dapat melanjutkan kaum mereka menurut garis ibu. Kalau suatu kaum punah, maka semua harta pusaka akan jatuh kepada anggota kaum yang lain. Kepunahan ini adalah sesuatu yang sangat mengerikan. Bila sebuah kaum punah, harta pusaka mereka berpindah tangan dan mereka tidak akan pernah lagi disebut-sebut (Hadi, 2013: 48).

Kaum Rumah Bagonjong menganut sistem matrilinel yang sangat mengandalkan dan membanggakan garis keturunan dari silsilah perempuan. Jika suatu kaum tidak memiliki anak perempuan, dapat dipastikan lambat laun kaum tersebut akan punah karena tidak ada lagi penerus dari kaum tersebut.

Kelanjutan suatu turunan ditentukan ada atau tidaknya perempuan di dalam suatu kaum. Perempuan itu kemudian melahirkan anak-anaknya. Anak-anak itulah nanti yang akan menerima warisan berikutnya. Jika di antara anak-anak itu tidak ada pula yang perempuan, maka akan punahlah kaum itu (Hadi, 2013: 48).

Oleh karena hukum adat yang demikian, kaum Rumah Bagonjong begitu sangat menyayangi Ci Inan sebagai satu-satunya generasi yang akan melanjutkan keturunan kaum Rumah Bagonjong. Kaum Rumah Bagonjong sangat berharap dari $\mathrm{Ci}$ Inan agar dirinya menjadi penerus kaum tersebut.
Ci Inan sendiri justru membalas kasih sayang saudara-saudara laki-lakinya dengan sebuah persoalan yang sengaja disembunyikannya sebab akan mendatangkan rasa malu. Mereka tidak berpikir bahwa dengan disembunyikan rahasia tersebut justru akan memperbesar rasa malu yang akan diterima jika rahasia tersebut terbongkar.

Perceraian bagi siapapun akan selalu dihindari. Jika masih dimungkinkan ada jalan keluar lain selain perceraian, niscaya jalan tersebut yang akan ditempuh. Begitu pula dengan keluarga $\mathrm{Ci}$ Inan. Apapun yang akan terjadi $\mathrm{Ci}$ Inan lebih memilih bertahan bersama suaminya daripada harus melepaskan suami demi menuruti tuntutan kakak-kakaknya untuk mengungkapkan persoalannya yang bersifat rahasia.

Dalam hal itu, tidak hanya Ci Inan yang merasa ketakutan jika perceraian itu sampai terjadi. Saudara laki-laki $\mathrm{Ci}$ Inan justru akan menanggung beban yang lebih berat. Selain urusan materi dan tanggung jawab, aib yang akan dipikul keluarga rumah Bagonjong akan semakin banyak.

Namun, yang ditakutkan, kalau-kalau nanti $\mathrm{Pa}$ Lendo, semenda yang selalu akan menyembelih orang itu, tersinggung dan pergi meninggalkan $\mathrm{Ci}$ Inan serta anak-anaknya. Cerai. Seandainya terjadi perceraian, keluarga Rumah Bagonjong akan semakin bertambah malu lagi. Hal ini sangat dihindari. Baik oleh $\mathrm{Ci}$ Inan sendiri maupun Pa Rarau atau Pa Tandang (Hadi, 2013:45).

Etnis Minang secara kultural masih menjunjung tinggi rasa malu terkait dengan perilaku yang melanggar norma sosial. Rasa malu tersebut bisa menimpa pada seluruh keluarga kaum ketika ia melakukan sesuatu yang keluar dari nilai yang telah diyakini selama ini. Karakter tokoh yang dihadirkan memiliki kekhasan yang sengaja mendua dalam menyikapi sesuatu. Meski orang menyimpan rahasia malu pada akhirnya ia akan malu juga menghadapinya ketika rahasia tersebut terbongkar. Rasa malu belum terbongkar secara nyata, tetapi dapat dikatakan malu yang dihidden-kan atau masih tersimpan rapat.

\section{Simpulan}

Persoalan identitas dan etnisitas selalu dipadu dalam konstruksi budaya sehingga 
memberikan ciri khas budaya yang dimiliki oleh masyarakat. Rumah Bagonjong sebagai identitas yang memperkuat keberadaan masyarakat Minang dengan atribut yang menyertainya dan bahkan cemoohan yang diungkapkannya. Berbagai masalah yang dihadapi seputar rumah Bagonjong tidak membuahkan hasil karena semua berbeda pendapat dalam menyelesaikan persoalan. Persoalan demi persoalan muncul, tetapi tidak ada solusi yang dihasilkan. Wisran Hadi menghadirkan sisi Minang dengan segala gejala sosial yang muncul, baik untuk kepentingan subjektivitas maupun komunitas yang menyisakan masalah.

Pembicaraan adat dalam kacamata Wisran menjadi sesuatu yang penting karena hal itu tidak dapat dilepaskan dari identitas masyarakat. Cara pandang dalam memahami adat pada masyarakat Minang dihadirkan sebagai upaya untuk mengkomunikasikan masalah yang khas tentang kaum dalam perspektif pengarang yang melahirkan novel itu.

\section{DAFTAR PUSTAKA}

Anwar, Ahyar. 2012. Teori Sosial Sastra. Yogyakarta: Penerbit Ombak.

Bardara, Aris. 2012. Analsis Wacana Teori, Metode, dan Penerapannya pada Wacana Media. Jakarta: Kencana Pernada Media Group.

Danardana, Agus Sri. 2012. "Identitas dan Etnisitas (Melayu)", (Online), (http://media-sastraindonesia.blogspot.com/2012/01/identitas-dan-etnisitas-melayu.html.), diakses pada tanggal 2 September 2013.

Hadi, Wisran. 2013. Persiden . Yogyakarta: Bentang.

Ratna, Nyoman Kutha. 2011. Sastra dan Cultural Studies Representasi Fiksi dan Fakta. Yogyakarta: Pustaka Pelajar.

Ratna, Nyoman Kutha. 2011. Antropologi Sastra: Peranan Kebudayaan dalam Proses Kreatif. Yogyakarta: Pustaka Pelajar.

Sugiarti, 2009. "Telaah Estetika dalam Novel Nayla karya Djenar Maesa Ayu". Atavisme Jurnal Kajian Sastra. Volume 12, Nomor 1, Edisi Juni 2009, Hal. 65-76.

Sugiarti. 2009. "Analisis Kritis New Historicism terhadap Novel Indonesia Modern dalam Kerangka Sejarah Sastra" . Litera Jurnal Penelitian Bahasa, Sastra, dan Pengajarannya. Volume 8 Nomor 2, Oktober 2009. Hal. 165-178.

Sugiarti, 2011. "Utilitas Bahasa dalam Mengkonstruksi Hegemoni Kekuasaan pada Novel Ronggeng Dukuh Paruk, Lintang Kemukus Dini Hari dan Jantgera Bianglala Karya Ahmad Tohari dalam Perspektif Antropologi Linguistik". Kajian Lingusitik Sastra Jurusan PBS FKIP UMS. Vol. 23, No. 2 Desember 2011, Hal. 187-2003.

Sugiarti, 2013. Representasi Konteks Sosial Novel 200-an dan Sumbangannya terhadap Kesusasteraan Indonesia. Hasil Penelitian Fundamental. DPPM Universitas Muhammadiyah Malang.

Suseno, Magnis Franz. 1995. Filsafat Kebudayaan Politik. Jakarta: Gramedia Pustaka Utama.

Suyitno. 1986. Sastra Tata Nilai dan Eksegesis. Yogyakarta: Handindita.

Wibowo, A. Setyo. 2004. Gaya Filsafat Nietzsche. Yogyakarta: Galang Press. 